\title{
Rabies Neutralizing Antibody Detection by Indirect Immunperoxidase Serum Neutralization Assay Performed on Chicken Embryo Related Cell Line
}

\author{
Tereza Cristina Cardoso/ ${ }^{+}$, Luzia Helena Q ueiroz da Silva, Avelino Albas/ ${ }^{++}$, \\ Helena Lage Ferreira*, Silvia Helena Venturoli Perri
}

\author{
Departamento de Apoio, Produção e Saúde Animal, Curso de Medicina Veterinária, Unesp, Campus de Araçatuba, Rua Clóvis \\ Pestana 793, 16050-680 Araçatuba, SP, Brasil *Instituto de Biologia, Regional de Presidente Prudente, Presidente \\ Prudente, SP, Brasil
}

The aim of this study was to evaluate the indirect immunoperoxidase virus neutralization (IPVN) and mouse neutralization test (MNT) to detect antibodies against rabies virus from vaccinated dogs and cattle. The IPVN was set up for the ability to measure 0.5 International Units/ml (IU) of antibody required by the World Health Organization and the Office International des Epizooties as the minimum response for proof of rabies immunization. IPVN was developed and standardized in chicken embryo related (CER) cell line when 141 dog and 110 cattle sera were applied by serial five-fold dilutions (1:5, 1:25, 1:125) as well as the positive and negative reference controls, all added in four adjacent wells, of 96-well microplates. A $50 \mu \mathrm{l}$ amount of $\mathrm{CVS}_{32}$ strain dilution containing 50-200 $T C I D_{50} / \mathrm{ml}$ was mixed to each serum dilution, and after $90 \mathrm{~min} 50 \mu \mathrm{l}$ of $3 \times 10^{5} \mathrm{cells} / \mathrm{ml}$ cell suspension added to each well. After five days of incubation, the monolayers were fixed and the IPVN test performed. The correlation coefficient between the MNT and IPVN performed in CER cells was $r=0.9949$ for dog sera $(n=100)$ and $r=0.9307$ for cattle sera $(n=99)$, as well as good specificity $(94.7 \%)$, sensitivity $(87.5 \%)$, and agreement $(96.6 \%)$ were also obtained. IPVN technique can adequately identify vaccinated and unvaccinated animals, even from low-responding vaccinated animals, with the advantage of low cost and faster then MNT standard test.

Key words: rabies virus - neutralizing antibodies detection - chicken embryo related cell - indirect immunoperoxidase assay mouse neutralization test

Rabies is a fatal zoonotic viral infection of central nervous system that is transmitted by bite of a rabid animal and is capable of infecting all mammal species. In most modern laboratories it is usually diagnosed by the detection of viral antigen in the brain by using a direct fluorescent antibody test (King 1966, Habel 1996, Bingham \& Merwe 2002). Considerable progress has been achieved in rabies prophylaxis in Brazil, mainly by the use of screening a large number of clinical samples by fluorescent antibody test and also by increase the vaccination programs, that results in a marked decrease in cases of urban and rural rabies (Rodrigues da Silva et al. 2000, Bordignon et al. 2002). Actually, tissue culture techniques have long been applied in studies related to rabies virus, and there are now a number of continuous cell lines used in research on pathogenesis, vaccine production, diagnosis of rabies, and measurement the respective immune response (Habel 1996, Smith et al. 1977, Bussereau et al.

Financial support: Fapesp, Proc. 00/07967-4

${ }^{+}$Corresponding author. Fax:+55-18-3622.6487.E-mail: tcardoso@fmva.unesp.br

${ }^{++}$PIBIC/CNPq fellowship

Received 5 April 2004

Accepted 30 June 2004
1982, Bordignon et al. 2001). It has listed over 41 cell types from different animal origins susceptible to rabies infection. Recently, has been demonstrated a new cell type, C6 rat glioma cells (clone CCL-107) susceptible to wild strains isolation (Bordignon et al. 2001). In fact, the $\mathrm{BHK}_{21}$ (clone 13) and chicken embryo related (CER) cell line cells were the first cell lines reported to be suitable for routine diagnosis, however only $\mathrm{BHK}_{21}$ has been reported for antibodies detection (Smith et al. 1977, Bussereau et al. 1982). Since then, the CER cells has been extensively studied and cited to be the only cell line capable to show cytopathic effect (CPE) and plaque formation caused by rabies infection, otherwise there is no report on CER cells used for neutralizing antibodies tests (Smith et al. 1977, Bussereau et al. 1982).

Afterwards, the assessment of the efficacy of rabies vaccination campaigns requires blood sampling of vaccinated animals to measure the respective immune response (Strady et al. 2000). The most commonly used techniques for this purpose are the serum neutralizing methods performed on mice or cell culture (King 1966, Atanasiu 1967, Habel 1996). The World Health Organization (WHO) recommended the mouse neutralization test (MNT) and the rapid fluorescent focus inhibition test (RFFIT) performed on $\mathrm{BHK}_{21}$ cells as standard techniques (Habel 1996).

In this paper, the potential utilization of CER cell line for rabies neutralizing antibody detection was assessed 
with sera from both vaccinated cattle $(\mathrm{n}=110)$ and dogs $(n=141)$. Moreover, the standardization of indirect immunoperoxidase virus neutralization (IPVN) technique using the CER cell line demonstrated a strength correlation between IPVN and MNT, and has an advantage of not using the fluorescent technique and specific microscopy evaluation to compute the results.

The CER line, passage 45, was kindly obtained from Laboratory of Viral immunology, University of Campinas, Campinas, São Paulo, Brazil. CER cell line was cultured with Dulbecco's modified Eagle's medium nutrient mixture F-12 (Invitrogen, Carlsbad, CA, US), supplemented with $2 \mathrm{mM}$ glutamine, $10 \%$ (v/v) foetal calf serum (Sigma Chemical, Co., St Louis, MO, US) and 1x antibiotic/antimycotic solution (Invitrogen) at $37^{\circ} \mathrm{C}$ in a moist atmosphere containing $5 \%(\mathrm{v} / \mathrm{v}) \mathrm{CO}_{2}$. Prior to use in the virus propagation procedure, the cells were trypsinized with $0.25 \%$ (w/v) Trypsin-EDTA solution (Invitrogen) and dissolved at concentrations indicated below (Bussereau et al. 1982).

The Challenge Virus Standard $\left(\mathrm{CVS}_{32}\right)$ strain of rabies virus was derived from reference stocks held by the Instituto Biológico, São Paulo, Brazil. Confluent monolayers of CER cells were cultured in 96-well tissue culture plates (Corning, New York, NY, US). Virus production was performed using $500 \mu 1$ of stock $\mathrm{CVS}_{32}$ suspension containing $10^{6,7}$-tissue culture infectious dose $50 \%\left(\mathrm{TCID}_{50}\right.$ ' $\mathrm{ml}$ ) were add to a confluent monolayer containing $3 \times 10^{5}$ cells pre-filtrated through $0.25 \mu \mathrm{m}$. After $60 \mathrm{~min}$ at $37^{\circ} \mathrm{C}, 5$ $\mathrm{ml}$ of medium with $2 \%$ foetal serum were add and the cultures incubated for 5 days after infection at $37^{\circ} \mathrm{C}$ in $5 \%$ $\mathrm{CO}_{2}$. The respective CER infection was done twice. The supernatant was removed to virus detection by mouse inoculation test (MIT) and respective monolayers were fixed with $80 \%$ (v/v) cold acetone for 15 min on a ice bath. The cells were stained for $1 \mathrm{~h}$ at $37^{\circ} \mathrm{C}$ with a rabies antiRNP conjugate (Sanofi Diagnostics Pasteur, France) diluted 1/20 in PBS containing 1/200 evans blue solution. After rinsing with buffered glycerine, the plates were examined with a 100X oil-immersion objective (Bingham \& Merwe 2002).

Purified $\mathrm{CVS}_{32}$ was prepared according to described in detail before (Sugiyama et al. 1997). The second antibody was produced in mouse. Briefly, ten adult mice were inoculated intra-muscularly with $250 \mu \mathrm{g}$ (in $0.03 \mathrm{ml}$ ) of $\mathrm{CVS}_{32}$ suspension emulsified with an equal volume of Freund's complete adjuvant. The imunization was performed three consecutively times, and 28 days after the first injection, the respective animals were boosted with $150 \mu \mathrm{g}$ of purified $\mathrm{CVS}_{32}$ with no adjuvant. After further 14 days the animal were bled, the serum separated and stored at $-20^{\circ} \mathrm{C}$.

A total of 251 serum (141 urban dogs and 110 cattle), vaccinated against rabies were individually studied by taking the respective blood sample randomly. These animals were characterised as being from rabies endemic area localized in southeastern of state of São Paulo, Brazil submitted to normal vaccination performed by regional programs. Vaccination histories were provided for all samples tested. In addition, sera from not vaccinated animals were included to calculated the sensitivity of serological tests.
IPVN test was performed as described before (Sugiyama et al. 1997). Briefly, serial twofold dilutions of heat inactivated $\left(56^{\circ} \mathrm{C}, 30 \mathrm{~min}\right)$ test sera were mixed with an equal volumes of $100 \mathrm{TCID}_{50}$ of $\mathrm{CVS}_{32}$ strain. After incubation for $60 \mathrm{~min}$ at $37^{\circ} \mathrm{C}, 50 \mu \mathrm{l}$ of the serum-virus mixture and $100 \mu 1$ of CER cell suspension $\left(3 \times 10^{5} \mathrm{cell} / \mathrm{ml}\right)$ were dispensed into each of four wells per serum dilution in 96-well tissue culture microtiter plates (Corning). The cells were incubated for 6 days in a humidified $5 \% \mathrm{CO}_{2}$ incubator and then fixed with 30\% acetone and $70 \%$ methanol for $15 \mathrm{~min}$. Viral antigen in the fixed monolayer was detected by immunoperoxidase staining. In brief, the fixed monolayers were reacted with anti-CVS 32 strain mouse serum, followed by peroxidase anti-mouse immunoglobulin G goat serum (Sigma). The reaction was visualized with substrate $0.5 \mathrm{mg}$ of o-phenylenediamine dihydrochloride per $\mathrm{ml}$ and $3 \% \mathrm{H}_{2} \mathrm{O}_{2}$ (Sigma) and stopped with $5 \mathrm{~N} \mathrm{H}_{2} \mathrm{SO}_{4}$. The VN titer to rabies virus was expressed as the reciprocal of highest serum dilution at which $50 \%$ or more of the wells showed a positive brown signal. In order to compare the efficiency of the IPVN described here, all the sera were submitted to a standard titration using the method described previously, the MNT described previously (Habel 1996). The respective titres were calculated using the Reed and Muench method (Reed \& Muench 1938) and the standard reference serum was diluted to contain 5 $\mathrm{IU} / \mathrm{ml}$ in each test. By comparison to the reference serum, results of test sera were reported as positive (test serum $\geq$ to titre of reference serum at $0.5 \mathrm{IU} / \mathrm{ml}$ ) or negative (test serum < titre of the reference serum at $0.5 \mathrm{IU} / \mathrm{ml}$ ).

The results were analyzed to determine relative sensitivity and specificity, predictive values and accuracy (Gamoh et al. 1996, Rooijakkers et al. 1996, Strady et al. 2000). Sensitivity was defined as the proportion of positive results obtained by standard technique that were correctly identified by the two serological methods applied in this study. Predictive values (positive and negative) were defined as the proportion of two tests, both positive and negative, which were corrected. Fisher's exact test was used to compared the sensitivity and specificity of two tests. The IPVN values were linearly regressed on standard method values, and the correlation coefficient (Pearson's $r$ ) was obtained. Kappa (k) was calculated to measure the strength of the agreement between the methods. The likelihood ratio at $95 \%$ confidence interval (CI) was used to express the probability that both IPVN and MNT results came from animals with opposed standard ones. For this purpose, the likelihood ratio for a positive test was defined as sensitivity/(1-specificity) and the likelihood ratio for negative test was defined as (1sensitivity)/specificity. StatsDirect (CamCode, Ashwell, England) and EXCELL97 (Microsoft, Bellevue, Washington) were used for the calculations.

Issues of specificity, sensitivity, and reproducibility must be considered when serological tests are compared. The use of well-characterized biological agents, known reference standards and high quality reagents in daily procedures helps to prevent erroneous results; however, diagnostic tests that employ biological systems such as virus neutralization are inherently variable. In comparative tests of two methods for measuring rabies neutraliz- 
ing antibody, we could find no mainly differences between the established method for ant-rabies antibodies (MNT) and the newer one (IPVN), as shown by the $96.6 \%$ of agreement obtained (data not showed). Test to test variability is unavoidable in a biological assay. Fortunately, with the high potency of veterinary vaccines (Rooijakkers et al. 1996, Cleaveland et al. 1999, Katayama et al. 1999, Cliquet et al. 2000) currently available worldwide, almost all vaccinated animals, dogs and cattle, should have neutralizing antibodies levels well above 0.5 IU minimum level required. However, in Brazil, the occurrence of rabies among animals supposedly protected by rabies immunization is not uncommon among cattle breeders (Rodrigues da Silva et al. 2000). The most reasonable answer, is the fact that rabies vaccination is not totally compulsory for these specie and the great variability in the respective level of vaccine production.

The most important finding from this comparative study is that he $0.5 \mathrm{IU}$ minimum level is sufficient stringent, nevertheless false positive reading has been made (5.3\%). In this regard, the IPVN was specific (94.7\%) in 199 sera from dog and cattle immunized contained $<0.5$ IU neutralizing activity according to results obtained before (Briggs et al. 1998). The data showed in our study have demonstrated for the first time the ability of IPVN performed in CER cells to titrated sera from two different species. The interpretation was easy, when the positive brown signal was detected strongly in negative sera (data not shown), and weak brown signal detected from positive sera from both species studied. The interpretation was recorded from the slides in a light normal microscopy, which can simplify the analysis when compared with fluorescence staining. The value of correlation coefficient reported here shows that there was a good relation between results obtained with MNT and IPVN for dogs and cattle, $r=0.9949$ and 0.9307 , respectively (Figure). These results were similar and higher to those reported before (Favoretto et al. 1993, Gamoh et al. 1996, Sugiyama et al. 1997, Briggs et al. 1998, Cleaveland et al. 1999, Katayama et al. 1999, Cliquet et al. 2000) when the ELISA and RFFIT methods were used for the same purpose.

Finally, the great advantages of IPVN described here over MNT conventional method, are safety issues of test performance, cost of reagents and equipment and time of reading test results, comparing to RFFIT and MNT, respectively.

\section{REFERENCES}

Atanasiu P 1967. Titrage des anticorps rabiques pratiqué sur les sérums humaines. Bull Off Int Épizzot 67: 383-387.

Bingham J, Merwe MV 2002. Distribution of rabies antigen in infected brain material: determining the reliability of different regions of the brain for rabies fluorescent antibody testing. J Virol Meth 101: 85-94.

Bordignon J, Comini F, Ferreira SC, Caprorale GMM, Lima Filho JHC, Zanetti CR 2002. Calculating rabies virus neutralizing antibodies titres by flow cytometry. Rev Inst Med Trop São Paulo 44: 151-154.

Bordignon J, Piza AT, Alvarez-Silva M, Caporale GMM, Carrieri ML, Kotait I, Zanetti CR 2001. Isolation and replication of rabies virus in C6 rat glioma cells (Clone CCL-
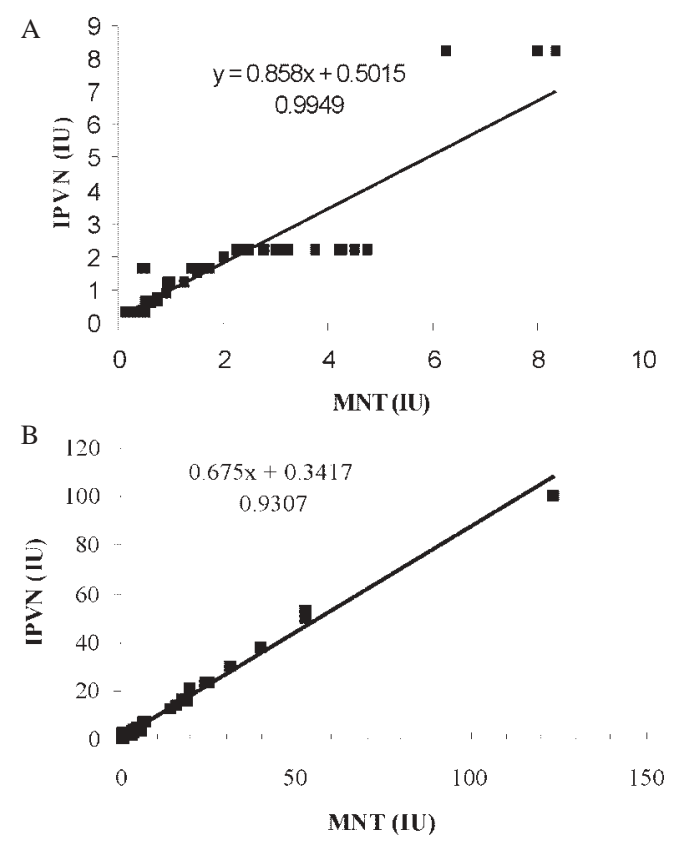

Linear regression line for antibody titers obtained by (y) indirect imunoperoxidase neutralization assay-IPVN (A) dogs and (B) cattle, and by (x) mouse neutralization test-MNT.

107). Biologicals 29: 67-73.

Briggs DJ, Smith JS, Mueller FL, Schwenke J, Davis RD, Gordon CR, Schweitzer K, Orciari L, Yager PA, Rupprecht CE 1998. A comparison of two serological methods for detecting the immune response after rabies vaccination in dogs and cats being exported to rabies-free areas. Biologicals 26 : 347-355.

Bussereau F, Flamand A, Pese-Part D 1982. Reproducible plaquing system for rabies virus in CER cells. J Virol Meth 4: $277-282$.

Cleaveland S, Barrat J, Barrat MJ, Selve M, Kaare M, Esterhuysen J 1999. A rabies serosurvey of domestic dogs in rural Tanzania: results of a rapid fluorescent focus inhibition test (RFFIT) and a liquid phase blocking ELISA used in parallel. Epidemiol Infectious 123: 157-164.

Cliquet F, Sagné L, Schereffer JL, Aubert MFA 2000. ELISA test for rabies antibody titration in orally vaccinated foxes sampled in the fields. Vaccine 18: 3272-3279.

Gamoh K, Senda M, Itoh O, Muramatsu M, Hirayama N, Koike R, Endoh YS, Minamoto N 1996. Use of ELISA for in vitro potency test of rabies vaccines for animals use. Biology 24: 95-101.

Favoretto SR, Carrieri ML, Tino MS, Zanetti CR, Pereira, OAC 1993. Simplified fluorescent inhibition microtest for the rabies neutralizing antibodies. Rev Inst Med Trop São Paulo 35: 171-175.

Habel K Habel test for potency 1996. In FX Meslin, MM Kaplan, H Koprowski (eds) Laboratory Techniques in Rabies, 4th ed., World Health Organization, Geneve, p. 369373.

Katayama S, Yamanaka M, Ota S, Shimizu Y 1999. A new quantitative method for rabies virus by detection of nucleoprotein in virion using ELISA. J Vet Med Sci 61: 411-416.

King AA 1996. Cell culture of rabies virus. In FX Meslin, NM Kaplan, H Koprowski (eds) Laboratory Techniques in Rabies, 4th ed., World Health Organization, Geneve, 1996, 
p. $114-130$

Reed LJ, Muench HA 1938. A simple method of estimating fifity per cent end-points. Am J Trop Med Hyg 27: 493497.

Rodrigues da Silva AC, Caporale GMM, Gonçalves CA, Targueta CA, Comin F, Zanetti CR, Kotait I 2000. Antibody response in cattle after vaccination with inactivated and attenuated rabies vaccines. Rev Inst Med Trop São Paulo 42: $95-98$.

Rooijakkers EJM, Uittenbogaard JP, Groen J, Osterhaus ADME 1996. Rabies vaccine potency control: comparison of ELISA systems for antigenicity testing. J Virol Meth 58: 111-119.
Smith AL, Tignor GH, Mifune K, Motohashi T 1977. Isolation and assay of rabies serogroup viruses in CER. Intervirology 8: 92-99.

Strady C, Jaussaud R, Béguinot I, Lienard M, Strady A 2000. Predictive factors for the neutralizing antibody response following pre-exposure rabies immunization: validation of a new booster dose strategy. Vaccine 25: 2661-2667.

Sugiyama M, Yoshiki R, Tatsuno Y, Hiraga S, Itoh O, Gamoh K, Minamoto N 1997. A new competitive enzyme-linked immunosorbent assay demonstrates adequate immune levels to rabies virus in compulsorily vaccinated Japanese domestic dogs. Clin Diag Lab Immunol 4: 727-730. 